\title{
The Description of Rubber Farmer Management in Sibiru Biru Sub-district, Deli Serdang Regency, North Sumatra and Its Response to the Introduction of Tapping Technology
}

\author{
Sumihar Hutapea ${ }^{1}$, Tumpal HS Siregar ${ }^{2}$, Suswati $^{3}$ \\ 1,2,3 Lecturer in Faculty of Agriculture, University of Medan Area, Medan, Indonesia \\ Email: sumihutapea@gmail.com
}

\begin{abstract}
:
Production of smallholder rubber in Indonesia is still very low, in the range of $600-900 \mathrm{~kg}$ of dry rubber/ha/year. Many factors influence it, such as non-clonal plants still being managed. Other factors such as agronomic aspects which include efforts to shorten the TBM period either through agronomic technology (canopy management, fertilization, or ground water management) are still ignored by smallholder rubber farmers, due to the limited access, capital, and even the perception that rubber plant production will not experience significant increase through tapping systems. The main and first approach that must be taken at this time on smallholder rubber is a new technology in tapping and management. This activity was carried out by four meetings and training in the garden of one of the trainees. Trainees consisted of rubber farmers in Sari Laba Jahe Hamlet, which also included rubber farmers from Peria Ria Hamlet - Sibiru Biru Sub-district (Deli Serdang Regency, North Sumatra). The package of tapping technology introduction consists of 3 main elements, namely: 1) tapping starts from the upper left to the lower right in each tapping field, 2) the application of $2.5 \%$ stimulant concentration is carried out in the tapping groove every 4 tapping times and 3) tapping in a month can be combined with tapping 1/S to the top using a pacekung tapping knife. Thus, in a month done 4 times of double cut tapping, namely 1/2S (in the lower tapping area using an ordinary tapping knife, downward: pull method) $+1 / 4 S$ (upward using a pacekung tapping knife: shearing method). The results of this activity show that it can increase the production, thereby increasing the volume of sap sold. This activity also shows that the dominant farmers manage 1 hectare of land, and with the planting year and planting material that have the potential to be increased in production through tapping systems. The survey results show that general knowledge about rubber cultivation is dominantly obtained from this activity.

Keywords:

production, tapping technology
\end{abstract}

\section{Introduction}

Production of smallholder rubber in Indonesia is still very low, in the range of 600 $900 \mathrm{~kg}$ of dry rubber / ha / year. Many factors influence it, such as non-personal plants still being managed. Other factors such as agronomic aspects which include efforts to shorten the TBM period either through agronomic technology (canopy management, fertilization, or ground water management) are still ignored by smallholder rubber farmers, due to limited access, capital, and even the perception that rubber plant production will not experience Significant improvement through the tapping system because the philosophy of injury definitely flows latex (Siagian, et.al, 2010). In other words, the attentions and perceptions of rubber farmers on tapping technology are very low because the fluctuations in their income from the plantation are more perceived because of price fluctuations. Rubber farmers will intensify tapping on the crops they manage when prices are high by not considering the longterm physiological aspects. Conversely, when prices are low, rubber farmers do not tap in their gardens because of low income (Siregar, 2004). In other words, rubber farmers do not apply 
technology and harvest management to their plantations in the face of these price dynamics.

These perceptions and habits of rubber farmers must be changed in order to obtain an increase in income through increased production. When looking at conditions in the field, the technological approach and management of smallholder rubber harvesting is not systemic (Sumarmadji and Junaidi, 2010). Aspects of tapping frequency, thickness and depth of tapped skin, systematic tapping, tapping time, number of plants tapped, and even equipment completeness are still conservative because they only consider that income increases can only be obtained through increasing market prices, not anticipating them by increasing production (Takuathung, 2006). The basis of high and low rubber production actually lies in tapping technology and management (Otene et.al, 2011). Management of new superior clones using a technological approach and conventional tapping management does not produce high production. Thus, the main and first approach that must be taken at this time on smallholder rubber is a new technology in tapping and management.

On the other hand, the Rubber Research Center has introduced a double cut tapping system, accompanied by well-planned tapping management so that production can be increased by up to $40 \%$. Based on observations in the field, it is known that some dominant factors that cause reduced production are the existence of deviant tapping norms or low tapping quality, the existence of limited tapping fields due to high branching points which are low and no less important is the existence of intensive tapping frequencies with the aim to pursue production targets. Low tapping quality is not only found in the top panel (H0) but also in the lower panel (virgin skin / B0). If the quality of tapping in panel B0 is low, it can be ensured that the production in the recovered skin (B1) will be low too. If the quality of tapping in the top panel is low, then what is certain to happen is that the production in panel B1 (although smooth recovery) will also be low (Siagian, Siregar, Sumarmadji, and Karyudi, 2010). This occurs due to the interruption of the phloem tissue which functions to transport assimilates from the top of the plant to the underlying tissue and damage to cambium which is a tissue that regenerates latex vessels. In order to achieve high productivity on an ongoing basis, the absolute thing is guided by the quality of tapping in accordance with established norms/rules.

This paper reports the PKM University of Medan Area (UMA), Medan, which introduced a tapping technology package as the main approach to increase production so that farmers get increased income, especially when rubber prices have not increased in the last 10 years. In other words, the increase of income is obtained through increased production.

\section{Research Method}

This activity was carried out by 4 meetings and training in the garden of one of the trainees. Trainees consisted of rubber farmers in Sari Laba Jahe Hamlet, which also included rubber farmers from Peria Ria Hamlet - Sibiru Biru Sub-district (Deli Serdang Regency, North Sumatra). The package of tapping technology introduction carried out were:

1. Tapping starts from top left to bottom right in each tapping area

2. The application of $2.5 \%$ stimulant concentration is done in the tapping groove every 4 times of tapping

3. Tapping in a month can be combined with tapping $1 / \mathrm{S}$ towards the top by using a pacekung tapping knife. Thus, in a month done 4 times of double cut tapping, namely $1 / 2 S$ (in the lower tapping area using an ordinary tapping knife, downward: pull method) $+1 / 4 \mathrm{~S}$ (upward using a pacekung tapping knife: shearing method) 
The observations made were to calculate production before applying the technology package above and after applying the technology package. Data and description of participating farmers were collected through a questionnaire, as well as farmers' expectations for further activities.

\section{Discussion}

\subsection{Description of Farmer Garden Management}

a. According to the area of the managed garden

From the farmers included in the survey, as many as 23.53\%) farmers (managing rubber plantations with an area of $0.5 \mathrm{ha}$, which is almost the same as farmers who manage rubber farmer covering an area of 1.5 ha, ie $17.65 \%$. While the rest manage gardens rubber with an area of 1 ha $47.06 \%$ and only $11.76 \%$ of farmers who manage a rubber plantation with an area of 2 ha (Figure 1). When rubber prices are low, it can only be done through tapping technology, in other words, it is necessary to maximize production with a tapping technology approach when rubber prices are low.

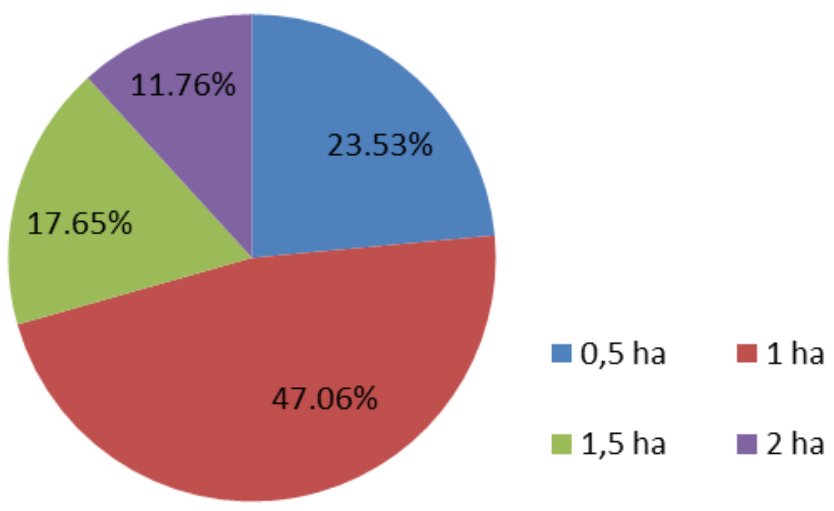

Figure 1. Distribution of farmers acoording to area of rubber plantation management

From this parameter it can be seen that with the dominant rubber plantation area of only 1 ha, when the price of rubber continues to be low, the area of the plantation cannot generate decent income for farmers. With an average yield of only 30-50 kg of wet per week, then with an average rubber price of Rp.7,000 per $\mathrm{kg}$ of wet, income of Rp. 210,000 Rp.350,000 a week is inadequate for the life of a farming family. On that basis, a number of farmers then made rubber tapping as a secondary activity, and sand mining activities as the main activity. This phenomenon is mainly found in mothers. The factor of the number of plants tapped per unit area is also a determining factor of production. Observations show that the number of plants per ha is not standard, that is 500 plants, but $<350$ plants. This factor makes the tapping done by farmers no longer systemic because in the end the heavy tapping is done on plants that are still available. Some plants also suffer from dryness of the tapping channel (panel dryness), so farmers do not make alternative tapping on other tapping fields on the same tree. In other words, farmers do not have the knowledge to tap in other fields of tapping so that plants that experience dryness become unproductive.

b. According to the planting year

When viewed from the age of the plant managed, $17.65 \%$ of farmers manage rubber plantations with planting years 1990 - 2000 or the same as farmers who manage rubber plantations with planting years $2000-2005$. As many as $64.71 \%$ of farmers manage rubber plantations with planting years $>2005$. This illustration shows that there is potential for plants 
to produce high production. Field observations show that the field of tapping has never been tapped and repeated tapping was carried out on B1-1 and B1-2, mainly on plants in 19902000. Visually, the tapping field which was dried up was no longer tapped but was tapped at the lower tapping field. still running latex sporadically. In other words, the wiretapping technology of the unknown tapping field should be introduced to explore production.

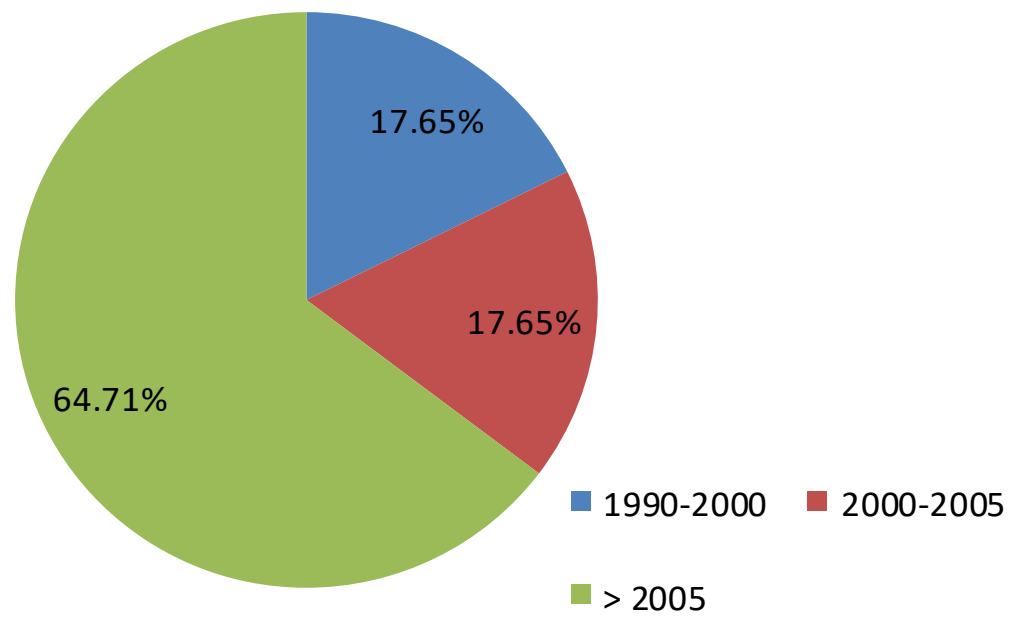

Figure 2. Distribution of farmers acoording to planting year of rubber that is managed

If you look closely, then basically the farmers' plantation in the village are still in the productive stage, ie $64.71 \%$ are 20 -year-old plants. At this age, tapping should have been done with double-tapping patterns, ie by tapping the lower tapping fields and the top tapping fields together, accompanied by the application of stimulants. Double cut tapping is proven to be able to increase yield up to $40 \%$, as confirmed by Siagian et.al (2010). This technology - when applied to rubber farmers while still controlling the quality of tapping also produces high production.

c. According to the type of planting material

The survey results show that farmers with grafting material are higher than seeds planting material, which is $70.59 \%$. While planting material is only $29.41 \%$ as presented in Figure 3. As is known, grafting planting material is a planting material that has the potential to produce higher production, in addition to the time the Immature Plant (TBM) is shorter than the planting material of seeds. However, $76.47 \%$ of farmers did not know the type of cloned tapping, only $23.53 \%$ knew that the clone tapped was PB 260. From discussions with farmers, the supply of grafting was obtained through the assistance of the Deli Serdang Regency Plantation Office, which details do not inform clone descriptions.
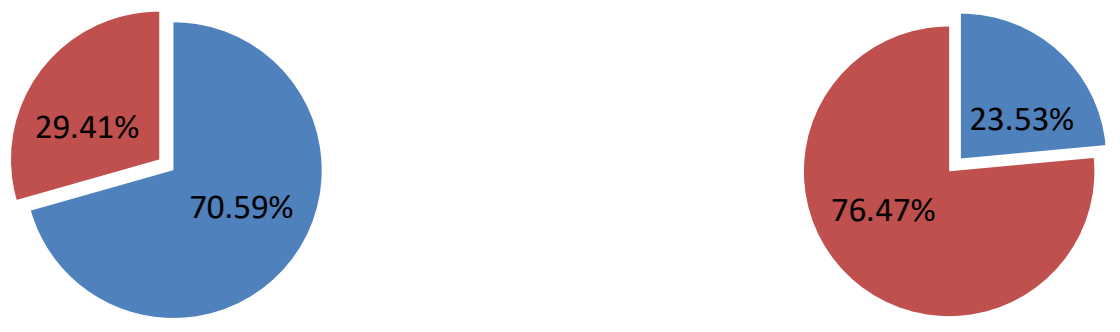

mGrafting $\quad$ Seed

Figure 3. Distribution of farmers according to planting material and their clones 
In a number of rubber plantations, besides the age of the plant, clone factor is also a consideration. In other words, planting material is a determinant of high production. With this approach, a number of clones were even able to produce up to $2500 \mathrm{~kg}$ dry / ha / year (Sumarmadji and Junaidi.2010). From observations and questionnaires obtained that only $23.53 \%$ of farmers who manage rubber plants with superior clones PB 260, the rest do not know the type of clones planted. The risk is again, there are still $29.41 \%$ of farmers who manage their rubber plants with the source of planting material (seedling). Plants derived from seeds will not produce high production, although it is accompanied by double cut technology and the application of stimulants. In other words, from the aspect of planting material this factor becomes an obstacle to increase production, even though the age factor of the plant has high potential, namely by not utilizing the field of tapping up.

\subsection{Plant Cultivation Practices}

a. Fertilization

As many as $41.18 \%$ of farmers had fertilized rubber plants, the same as other farmers who had never fertilized, or each of the number of farmers. Whereas $17.65 \%$ ) farmers do not remember whether or not to fertilize (Figure 4).

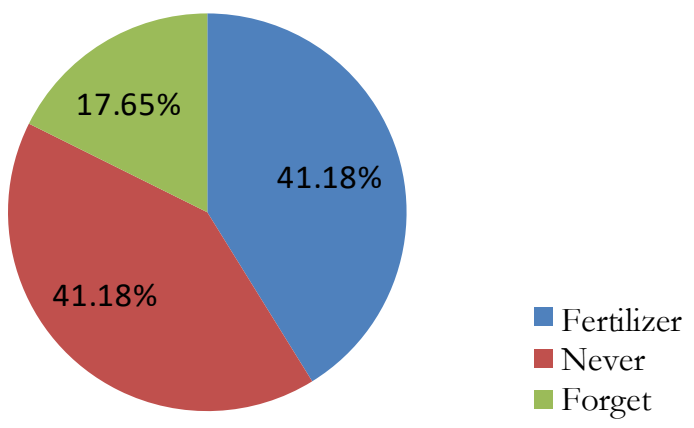

Figure 4. Distribution of farmers according to fertilizer practice

b. Disease and weed control

All farmers stated that the most alarming plantation disease was root disease, the White Root Mushroom (WRM). However, only 5.88\% of farmers have ever treated this disease. This information shows that the technology for controlling this disease is unknown, as well as fungicides (or sulfur) that can control it.

WRM is the most important disease in rubber plants, because of its high potential to cause fallen/broken plants from the base of the stem. This means that WRM disease can directly reduce the number of tapped plants. Specifically the farmers surveyed indicated that the control was carried out only manually. This disease basically has made the root as a host so that control since seeding is a major prerequisite, in addition to other maintenance factors such as sulfur sowing in the planting hole before the implementation of planting or sulfur sprinkling periodically after planting. 


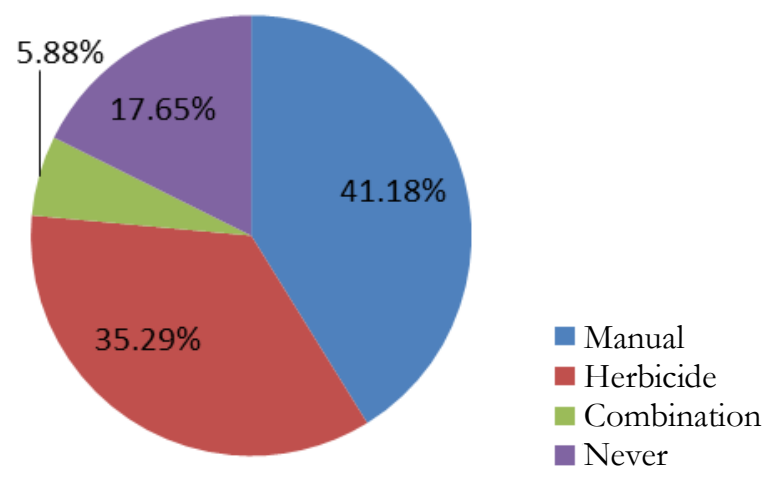

Figure 5. Distribution of farmers in weed control

In terms of weed control, farmers are more appreciative compared to other acts of cultivation. This is because weeds can inhibit the implementation of tapping from one plant to another. From Figure 5 it can be seen that as many as $41.18 \%$ of farmers control weeds manually, and $35.39 \%$ of farmers control weeds using herbicides. As many as $17.65 \%$ of farmers have never carried out weed control. Observations show that all three farmers have sloping land.

Besides WRM disease, the factor that has not yet become a priority is sugar control in the garden. Observations do show that weeds are a potential cause for two main things, namely: 1) host the leaf disease. The results of the discussion showed that leaf shrubs were experienced by farmers up to 2 times a year and examining fallen leaves concluded that Colletrichum sp. Had hit farmers' crops. Weeds that grow uncontrolled in the real garden become the host of the disease.2) the growth of weeds makes it difficult to harvest because tapping from one plant to another is not clean which in turn the farmer does not completely finish tapping for all plants in his garden. In other words, from the aspect of harvest management, weeds that are not controlled become a limiting factor in resolving tapping on all plants contained in the garden.

\subsection{Knowledge of Plantation Cultivation}

a. Tapping direction

The basic introduction of tapping done by tapping, directed from top left to bottom right shows that $70.59 \%$ of farmers have understood it, and $23.53 \%$ of farmers still do not understand this basic aspect of tapping. Whereas $5.88 \%$ of farmers tapped irregularly because the lower tapping fields had been tapped many times (Figure 6), or were old plants. Understanding this aspect becomes very important because by tapping from top left to bottom right the number of latex vessels are cut more than the opposite. 


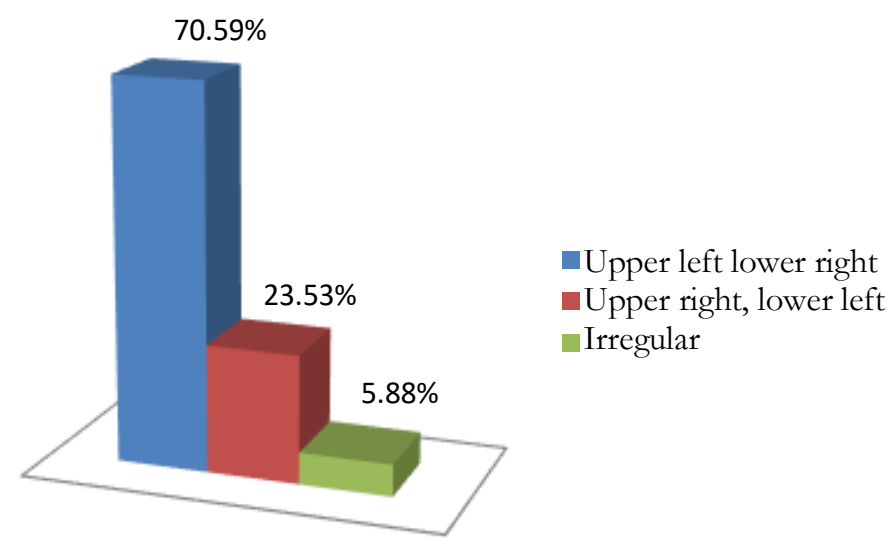

Figure 6. The knowledge of the direction of farmers tapping after the introduction of basic aspects of tapping

This becomes the main basis for tapping because basically the latex vessels grow from the bottom right to the upper left. Thus, the tapping must be done from the opposite direction to be able to cut more latex vessels. The observations showed that farmers who tapped irregularly generally managed old plants $(>20$ years), ie tapped many times the recovered skin which had lower production potential. In contrast, the tapping sector is not tapped, so that even though old plants are still being managed, the actual production potential is still contained in the upper tapping field.

b. General cultivation

The survey results showed that $35.29 \%$ of farmers obtained a comprehensive knowledge of rubber cultivation from PKM activities, namely the Faculty of Agriculture in University of Medan Area (Medan). While 17.675\%) farmers besides from these sources, also gained knowledge through their own experience, as well as fellow farmers as much as $11.76 \%$ of farmers, and from parents as much as $5.88 \%$ of farmers. As many as $29.41 \%$ of farmers did not answer the source of cultivation knowledge, as presented in Figure 7.

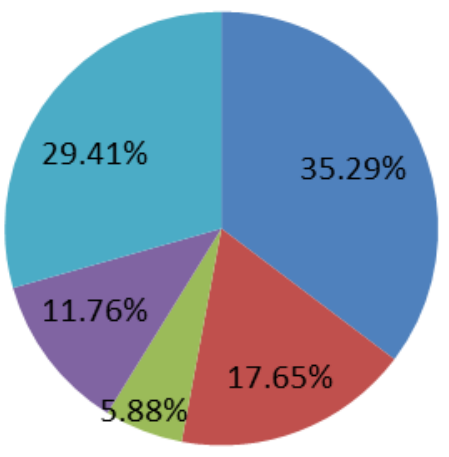

$$
\begin{aligned}
& \text {-FP UMA } \\
& \text {-Experience } \\
& \text { - Parents } \\
& \square \text { Fellow farmers } \\
& \text { Does not answer }
\end{aligned}
$$

Figure 7. Sources of cultivation knowledge obtained by farmers 
During the implementation of the activity, general counseling was also conducted regarding rubber cultivation and the results showed that $35.29 \%$ of farmers gained new knowledge in addition to the system and management of tapping as described material. When examined, farmers really need cultivation guidance in general, which can be seen from the farmers' expectations of activities related to community service.

\subsection{Increased Production}

The introduction of integrated tapping technology as presented in the above methodology results in an increase in production with the distribution presented in Figure 8.

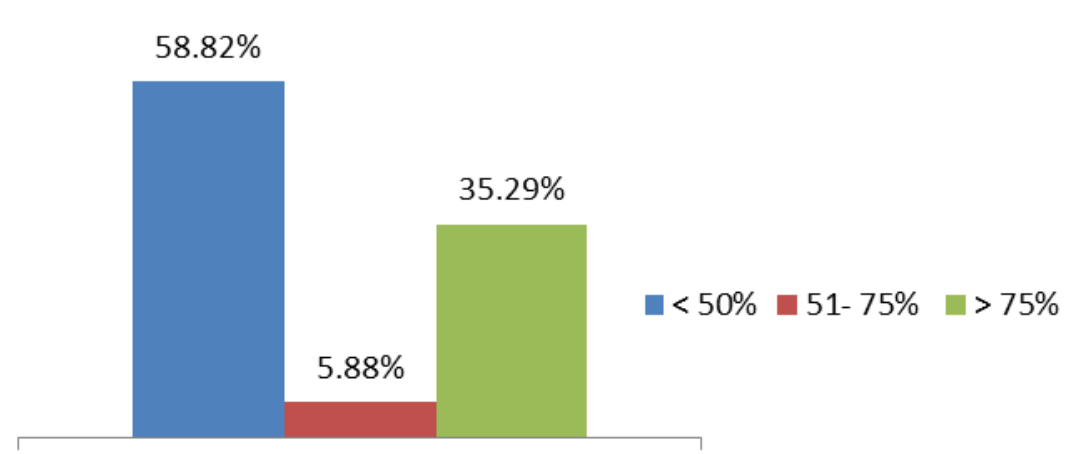

Figure 8. Distribution of increased production after the introduction of tapping technology

It can be seen from Figure 8 that as many as $58.82 \%$ of farmers experienced an increase in production $<50 \%$, and $5.88 \%$ of farmers experienced an increase in production in the range of $51-75 \%$ and there were $35.29 \%$ of farmers experienced an increase in production $>75 \%$. This increase in production is considered quite encouraging because the practice of farmers directly in their respective gardens directly increases daily production. This shows that the rubber tapping technology that is accompanied by the tapping management principles that have been applied by farmers does not produce adequate production, at a time when rubber prices continue to be low. In detail, the increase in production is presented in Table 1. From Figure 8 and Table 1 it can be stated that the introduction of tapping technology which is then applied to each farmer's garden is able to increase production, which has an impact on increasing the volume of sap sold. Thus, an increase in income of farmers who obtained tapping technology skills.

Table 1. Production data before and after the application of the technology package

\begin{tabular}{cccc}
\hline Name & $\begin{array}{c}\text { Before application of } \\
\text { the technology packages }\end{array}$ & $\begin{array}{c}\text { After application of the } \\
\text { technology packages }\end{array}$ & \% Increase \\
\hline \multicolumn{4}{c}{ Kg wet / week } \\
\hline WS & 65 & 68 & $4,62 \%$ \\
\hline AT & 30 & 80 & $166,67 \%$ \\
\hline Y & 33 & 60 & $81,82 \%$ \\
\hline JK & 50 & 60 & $20,00 \%$ \\
\hline APB & 80 & 85 & $6,25 \%$ \\
\hline PK & 80 & 90 & $12,50 \%$ \\
\hline PS & 50 & 100 & $100,00 \%$ \\
\hline IP & 70 & 75 & $7,14 \%$ \\
\hline BT & 80 & 90 & $12,50 \%$ \\
\hline EG & 90 & 100 & $11,11 \%$ \\
\hline
\end{tabular}




\begin{tabular}{cccc}
\hline JT & 80 & 150 & $87,50 \%$ \\
\hline RT & 50 & 90 & $80,00 \%$ \\
\hline KT & 45 & 60 & $33,33 \%$ \\
\hline RK & 100 & 120 & $20,00 \%$ \\
\hline J & 200 & 400 & $100,00 \%$ \\
\hline AT $^{2}$ & 20 & 35 & $75,00 \%$ \\
\hline HDYS & 40 & 60 & $50,00 \%$ \\
\hline
\end{tabular}

\section{Conclusions}

The results of this activity show that tapping technology were in the form of: 1) tapping starts from the upper left to the lower right in each tapping field, 2) the application of $2.5 \%$ stimulant concentration is carried out in the tapping groove every 4 tapping times and 3) tapping in a month can be combined with tapping $1 / \mathrm{S}$ to the top using a pacekung tapping knife. Thus, in a month done 4 times of double cut tapping, namely $1 / 2 S$ (in the lower tapping area using an ordinary tapping knife, downward: pull method) $+1 / 4 \mathrm{~S}$ (upward using a pacekung tapping knife: shearing method). can increase production, thereby increasing the volume of sap sold. The increase in production experienced by farmers was as much as $58.82 \%$ of farmers had increased production $<50 \%$, and as much as $5.88 \%$ of farmers had increased production in the range of $51-75 \%$ and as much as $35.29 \%$ of farmers had increased production $>75 \%$. This activity also shows that the dominant farmers manage 1 hectare of land, and with the planting year and planting material that have the potential to be increased in production through tapping systems. The survey results show that general knowledge about rubber cultivation is dominantly obtained from this activity

\section{Acknowledgment}

Thank you to Haji Agus Salim Foundation, University of Medan Area for providing funds to carry out the community service activities. Furthermore, we also thank you to the Chancellor and Chairperson of the University Research Institute who gave the Team the opportunity to carry out PKM activities. The authors also does not forget to thank all members of Mekar Tani Group, Sari Laba Jahe Village and Peria-ria Sibiru Biru Sub-district, Deli Serdang Regency (North Sumatra) who participated in this activity, specifically to Mr. Setia Budi Barus as the head of the farmer group.

\section{References}

Siagian,N., Tumpal HS Siregar, Sumarmadji and Karyudi. (2010). Potret umum pelaksanaan norma baku eksploitasi di beberapa perkebunan karet. Kumpulan makalah workshop eksploitasi.24p.

Siregar, Tumpal H.S. (2004). Fungsi, manfaat dan pelaksanaan tap inspeksi. makalah disampaikan pada latihan petugas tap inspeksi PT.Socfindo $6-8$ April 2004. Balai Penelitian Sungei Putih.Pusat Penelitian Karet.15p.

Sumarmadji and Junaidi. (2010). Sistem eksploitasi tanaman karet berdasarkan tipologi klon (quick dan slow starter).Balai Penelitian Sungei Putih.Pusat Penelitian Karet.2010.28p.

Takuathung. (2006). Rubber Plantations in Southern Thailand: management and social and economic functions. $28 \mathrm{p}$

Otene,F.G., C.P. O. Obinne and P.O.Egwumah. (2011). Evaluation of the utilization level of improved rubber management practices among farm Settlers in Edo and Delta states. J Agri Sci, 2(1): 53-60. 